\title{
交差形式を考慮した 機能的階層型道路ネットワークの評価
}

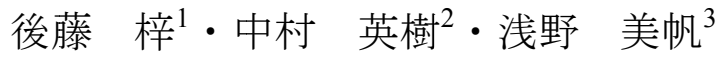 \\ 1学生会員 名古屋大学大学院 工学研究科 社会基盤工学専攻 博士後期課程 \\ ( 丁464-8603 名古屋市千種区不老町C1-2(651)) \\ E-mail: azusa@genv.nagoya-u.ac.jp \\ 2 正会員 名古屋大学大学院教授 工学研究科 社会基盤工学専攻 (同上) \\ E-mail: nakamura@genv.nagoya-u.ac.jp \\ 3 正会員 名古屋大学大学院助教 工学研究科社会基盤工学専攻 (同上) \\ E-mail: asano@genv.nagoya-u.ac.jp
}

\begin{abstract}
道路の機能に応じたサービスを提供する階層型ネットワークの概念は，国内外を問わずその重要性が認 識されてきた。特にわが国では, 幹線道路の混雑や生活道路における通過交通といった課題解消のため, 実用展開に向けた議論がおこなわれている。しかし，階層型ネットワーク実現の鍵となる交差形式の設定 が, 個別の道路やネットワーク全体の性能に及ぼす影響については, 計画段階においては定量的に検証さ れてこなかった。本論文では, 利用者均衡配分に交差点遅れを組み込むことでこれを明示的に評価可能な 手法を構築し, 格子状の仮想ネットワークを用いて検証した。その結果, 機能的階層化の実現には幹線道 路における交差点遅れの軽減が重要であること, これが実現した場合, 生活道路における交通静穏化対策 も有効的に機能することが示された.
\end{abstract}

Key Words : functionally hierarchical road network, junction types, delay, user equilibrium

\section{1. はじめに}

わが国では，幹線道路での啮滞や生活道路内の通過交 通などの問題を受けて，現状の道路ネットワークを機能 的階層型に再編する必要性が提唱されてきた1,22,3)など.

機能的階層型ネットワーク(以降，階層型ネットワー ク)とは, トレード・オフの関係にあるトラフィック機 能(交通を円滑に流す機能)とアクセス機能(沿道施設や生 活道路への出入のしやすさを表す)の優先度に応じて, 各道路を差別化し，異なるサービスを提供するよう設計 したネットワークである。つまり，トラフィック機能重 視の道路を上位階層と定義すると，階層が上がるにつれ て旅行速度は高くなり，アクセス間隔が大きくなるので, 比較的トリップ長の長いトリップのみに使用されるよう

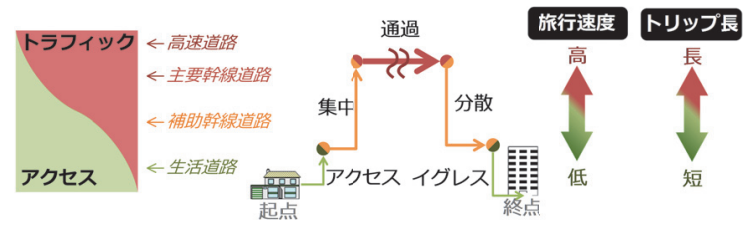

図-1ネットワークの機能的階層化
になる(図-1)。このとき，生活道路のような下位階層は 沿道施設とのアクセス/イグレスに使われ，幹線道路や 高速道路のような上位階層は長距離移動に使われる，と いうように階層に応じた道路の機能分担によって，効率 的なネットワーク運用が実現する.

このような機能的階層化の概念は，アメリカやドイツ など欧米諸国の計画指針にも導入されており，国内外を 問わずその必要性が認識されている. しかしながら，こ れを実現可能と寸る道路構造の検証や，効果の定量的評 価は充分行われてこなかった．このため，各指針が設定 する階層区分や階層別性能(サービス)目標によって, ネ ットワーク全体がどの程度の性能を達成するのか，逆に どのようにして性能目標を達成寸ればよいのかは明確に 示されていない，特に，階層間の接続関係・交差形式の 決定は性能目標達成の鍵となり，機能的階層化の維持に 大きく影響すると考えられている2湾孞，具体的な検討 手順は明確に示されてこなかった.

そこで本論文は，ネットワークにおける交差形式の変 更や交通静穏化対策が，機能的階層化の実現やネットワ 一クの性能に及ぼす影響について定量的評価を行うこと 
を目的とする，具体的には，階層の数・道路間隔・各階 層での自由走行速度・階層間の交差形式が与えられたと き，利用者均衡配分に基づいて階層別旅行速度やトリッ プ旅行時間を計算する手法を構築し, 簡易な格子状ネッ トワークを用いて, 交差形式・自由走行速度の変更を行 う階層化対策のシナリオ評価を行う。

\section{2. 階層型道路ネットワークの計画手順}

本章では, 現状の課題を整理した上で，階層型ネット ワーク実現のために必要な計画手順について, 各国のガ イドラインや既往研究を参考にしながら整理する.

\section{（1） 日本のネットワーク計画の課題と階層の必要性}

階層型ネットワークの必要性は, 日本の道路構造令の 解説と運用奋においても，「道路の果たすべき役割を十 分に踏まえたうえで, 道路利用者にとって必要な道路の 機能を確保」することや，「その機能の確保に必要な道 路構造について, 総合的に判断すること」として認識さ れている. しかし現実には，特に一般道において以下の ような問題があり，短距離トリップの幹線道路利用や通 過交通の生活道路進入といった, 本来意図される機能と 利用実態との不一致を引き起こしている.

問題-a: トラフィック機能を重視すべき上位階層の道路 であっても，多くの信号交差点や不十分な沿道アクセス 制限のために，頻繁に停止や遅れを被る

問題-b: アクセス機能を重視すべき下位階層の道路であ っても，ハンプやシケイン，狭窄部などの交通静穏化対 策はほとんどみられない

問題-c: 相反する機能を持つ上位階層と下位階層の道路 どうしが，容易に相互アクセス可能である

これらの問題の原因として, 日本の道路計画・設計段 階では，交通容量を基準とした評価しか行われておらず, 必要とするサービス水準は必ずしも担保されていないこ とが指摘されてきた5)。そもそも現行の道路計画では目 標サービス水準の設定すら行われない上，交通容量の評 価も単路部を基本としたものであり，交差部に関しては 4車線相互が交差する場合には立体交差という以外に規 定がない.このことが，上述のような問題を生み，結果 として階層別の機能分担が困難な状態を招いている.

したがって, 道路の計画・設計段階において, 機能に 基づいた道路階層区分と目標サービス水準の設定を行い, 道路の接続関係や交差形式の評価をしておくことが，階 層型ネットワーク実現のために不可欠であるといえる.

\section{（2）海外における階層型ネットワークの設定}

機能的階層化の概念に基づいた道路の計画・設計の代 表的な指針として，ドイツのRIN $(2008)^{\natural}$ がある. RINで
は，まずネットワーク全体の性能目標として，拠点間旅 行時間が拠点レベル(大都市間は3時間以内など)に応じ て設定される，道路の階層区分は，拠点レベルが示寸連 絡スケールと道路の種類によって決定される。ここでい う道路の種類は, 市街地/非市街地の別のほか, 沿道立 地の有無と道路機能(トラフィック/アクセス/滞留)によ って分けられている.これらが考慮された階層に応じて, 階層別性能目標である旅行速度の上限值と下限值が設定 されるため，これが達成されれば，階層に応じた段階的 なサービス水準の変化が実現する. 接続方法・交差形式 に関しても，地方中心都市間のような比較的長距離卜リ ップを担う道路と，個別施設からのアクセス道路とが接 続しないように規定されているほか, 各階層間の交差方 式の例示もされている. さらに, 交差形式や横断面構成 などの道路構造の詳細については, 階層別に設計指針が 提示されている(RASt など).

しかし，RINには，階層別目標旅行速度算出の根拠と なるべき，拠点間旅行時間と階層別旅行速度の定量的関

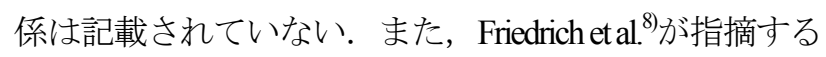
ように，ネットワークで実現される旅行速度と交差部形 式などの個別の道路構成要素との定量的関係も, 検証が 不十分な現状にある.

一方，アメリカでは道路計画指針(AASHTO Green Book $\left.{ }^{9}\right)$ にって, 階層の設定, 階層別性能目標(LOS)の 設定が行われるが, 高速道路・幹線道路・集散道路・生 活道路に区別された階層について, RINのようなネット ワーク性能目標との関係は示されていないほか, 目標 LOSの設定もRINに比べて漠然としている. 交差形式に 関しては, Green Bookには直接記述はなく, Access Management Manual ${ }^{10}$ などでアクセス制限や副道・中央分離帯 設置などが適宜推奨されているが，これも概念的なもの にとどまっている.

\section{（3）階層型ネットワーク実現のための手順と課題}

わが国では，(1)で述べた問題意識のもと，階層型ネ ットワークの実現のための計画・設計手順が議論され, 中村5), 下川( 3)や桑原ら ${ }^{11)}$ などによって, 図-2に表すよ うな二段階の性能評価としてまとめられてきた.

上位段階(図-2 (1))では, ネットワーク全体に与えられ る拠点間連絡性能目標を達成可能なように, 道路階層区 分および階層別性能目標(ここでは旅行速度を考える)を 決定する．このとき，「階層別目標旅行速度は必ず達成 されている」と仮定をおけば, 交通需要の影響を考慮す る必要はない。

下位段階(図-2 (2))では，上位段階で「必ず達成される」 と仮定していた階層別目標旅行速度を達成寸るための, 単路部および交差部の道路構造や交通制御を決定する. ここでは, 旅行速度が交通量に依存するため, 交通需要 


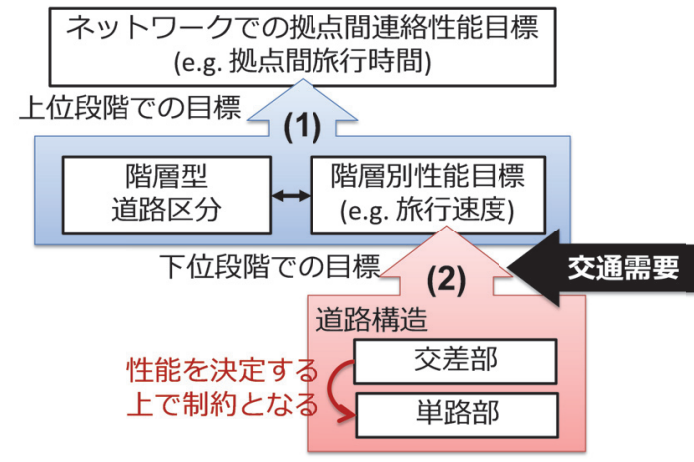

図-2 階層型ネットワーク実現のための計画手順

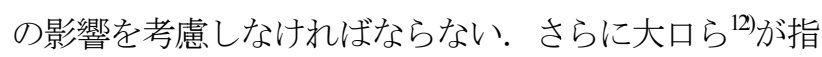
摘するように，一般道においては信号交差点などの平面 交差部がボトルネックとなっていることから，交差形式 の決定が，目標旅行速度の達成可否の鍵となる。 また， 上位階層の旅行速度低下によって発生する下位階層の通 過交通などの，各階層の利用状況を評価する上でも，交 通需要と交差形式の関係は非常に重要といえる.

これまでに，桑原ら ${ }^{111}$ は，上位段階の性能評価に主眼 を置き，階層別の道路間隔と目標旅行速度の違いが，ネ ットワーク平均旅行時間と旅行距離に与える影響を定量 化している. Miyagawa ${ }^{13}$ は，平均旅行時間を最小化する 道路密度を求めており, これも上位段階の評価に分類で きる.一方で，下位段階の性能評価方法については，こ れまで明示されてこなかった。道路の接続関係に着目し た研究として, Zhang and $\left.\mathrm{Li}^{14}\right)$ は情報地理科学の観点から, 道路の接続のしかたを考慮した階層の決定方法を提案し ているが，交通需要や旅行速度といった運用状態のこと は考慮されておらず，本研究が扱う機能的階層とは意味 の異なるものとなっている.

\section{3. 階層型ネットワーク評価のねらい}

本章では, 本研究が放らいとする階層型ネットワーク 評価の観点とそれに必要な評価指標について述べる.

\section{（1）「機能的階層化」という観点}

本研究によるネットワーク評価の観点は，意図した機 能的階層化が実現されているか, 利用者に提供されるサ 一ビス水準はどの程度となるかの二点に分けられる。 こ れは，2.(1)で述べたように，道路の接続関係・交差形式 や交通静穏化の影響によって階層性が保持されるかどう かが決まるため，どのような対策をとれば機能的階層化 が実現するかを検証した上で，利用者に対するサービス 水準を評価することが必要であるためである.

ここでいう機能的階層化の実現とは, 階層に応じた道 路の機能的役割分担が実現することに他ならない，すな わち，(a) 各階層の旅行速度が明確に差別化されている こと，特に上位階層で高い旅行速度が保たれていること， 加えて, (b) 下位階層で通過交通が排除されていること を確認する必要がある. (a), (b) のようなネットワーク特 性を確認した上で，(c)利用者に提供されるサービス水 準はどの程度となるかを評価する。

注意すべき点は, 本研究が目的とする機能的階層化の 観点に基づく評価を, 従来の交通容量に基づいた評価と は別次元として捉える点である. これは, 従来までの評 価が，単に需要と容量を比べて道路が飽和しないかどう かを確認するものだったのに対して，今回扱うのは，各 階層で必要容量は確保されている前提のもと，それぞれ のサービス水淮(旅行速度)をどうすべきかという議論で あるためである. このため, 過飽和が生じるネットワー クの場合は, 上述のような階層化の効果の評価対象とし て適切でない.

\section{(2) 評価指標}

上記(a) (c)に対応する評価指標として，本研究では以 下を用いる. これらは, 次章で説明する均衡配分の結果 から計算されるものである.

\section{a) 階層別平均旅行速度}

各階層が明確に差別化されているかの全体的傾向を把 握するため, また上位階層においてトラフィック機能が 確保されているかを確認寸るため, 階層別平均旅行速度 を用いる。階層別平均旅行速度は, リンク旅行速度 $v_{i j}=t_{i j} / l_{i j}\left(t_{i j}\right.$ は交差点遅孔を含むリンク旅行時間, $l_{i j}$ はリン ク長)と定義したとき, 各階層に属する全リンクのリン ク旅行速度の平均值とする.

この值は, 図-2 で示されるように, 道路構造を決定 する下位段階での性能評価指標であり, 実際の道路の計 画・設計では，階層別に設定されたある目標值を達成で きるように道路構造を決定することとなる.

\section{b) 通過トリップの各階層使用割合}

生活道路から通過交通が排除されることを検証する指 標として, 通過交通のトリップ長別に, 最短経路を使用 した場合の各階層使用割合 $=($ ある階層の走行台キ ロ)/(総走行台キロ)を定義する．ただし，本研究では確 定的配分により均衡解を導出するため, OD 間の利用経 路を特定できないので，全ての最短経路に等しく交通量 が配分されると仮定して算出几た.

\section{c) トリップ長別旅行時間}

機能的階層型ネットワークでは, トリップ長に応じて 使用できる階層が異なるため, 利用者が享受できるサー ビス水準もこれに依存する，そのため，トリップ長別旅 行時間を，ネットワーク性能の評価指標とする.

トリップ長は, 使用経路に左右されない純粋な起終点 間距離として定義する。これは，階層化対策後に，中央 
分離帯や立体交差によって迂回を余儀なくされた場合や, 上位階層アクセスがもたらす旅行時間短縮を目的とした 積極的な迂回が生じた場合にも，同じ值を基準として， 旅行時間やそのばらつきの変化を評価するためである.

また，基本となるシナリオ $\mathrm{S}_{0}$ に対して，対策 $\mathrm{A}$ を導

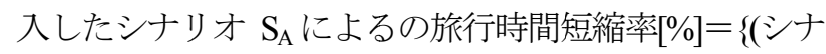
リオ $\mathrm{S}_{\mathrm{A}}$ での旅行時間)-(シナリオ $\mathrm{S}_{0}$ での旅行時間)\} / (シ ナリオ $\mathrm{S}_{0}$ での旅行時間) $\times 100$ をトリップ長別に評価す る.この短縮率が大きいほど, 対策によってあるトリッ プ長の利用者に対するサービスが向上したことを表す．

\section{4. 交差点遅れを考慮した利用者均衡配分手法}

接続関係や交差形式を変更した場合の影響を評価する ためには，交差点遅れの影響を考慮しながら，各階層で 達成される旅行速度と利用者の経路選択行動の相互関係 を把握する必要がある. このための手法として，本研究 では静的利用者均衡配分を用いる. これは, 詳細な入力 データを必要とする交通シミュレーションに比べ, 計画 段階においても入手が容易なデータのみから傾向を把握 できるためである. 本手法では, 各階層の道路の間隔と 自由走行速度, 交差形式を定義したネットワークシナリ オに対して，交差点遅れによる影響を考慮しながら，想 定されるOD交通需要を利用者均衡状態となるように配 分を行う.

\section{（1）交差点遅れを考慮した旅行時間関数の設定}

静的利用者均衡配分による均衡解を得るためには，リ ンク旅行時間を対象リンク交通量のみに依存する関数 (BPR関数など)として定式化し，収束計算を行うことが 一般的である. しかし本研究では, 交差形式によって対 象リンク以外の対向側・交差側リンク交通量が旅行時間 に及ぼす影響が異なることを表現することで，交差形式 の変更を適切に評価するため, これら複数方向からの流 入交通量の関数である交差点遅れを旅行時間に組み込む.

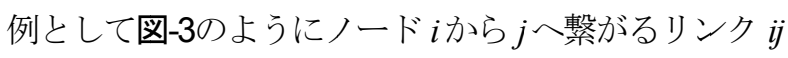
を考える.ここに，ノードは交差点，リンクは単路部を 表し，ノードjは四枝交差点とする.

本研究では, 利用者均衡問題を解くための, 旅行時間 と交通量の関係を式(1)のように定式化する. 式(1)は,

リンク旅行時間が自由走行速度からなる「単路部走行時 間」と交通量からなる「交差点遅れ」の和であることを 表している.

$$
t_{i j}\left(\mathbf{x}_{j}\right)=\frac{l_{i j}}{v_{f, i j}}+d_{i j}\left(\mathbf{x}_{j}\right)
$$

ここに, $t_{i j}$ : リンク $i j$ を移動するのに要する旅行時間, $l_{i j}$ : リンク $i j$ のリンク長, $v_{f i j}$ : 自由走行速度, $d_{i j}$ : リンク $i j$ から流入する際にノード $j$ で被る交差点遅れ, $\mathbf{x}_{j}$ : ノー ド $j$ に流入する各リンクの交通量からなるべクトル(図-3 では $\left.\mathbf{x}_{j}=\left\{x_{i j}, x_{\text {jij }}, x_{j ;}, x_{m j}\right\}\right)$ である.

この旅行時間関数は, 街路においては単路部での遅れ が交差点遅れに比べて無視できるとの仮定のもと, 単路 部は交通量に依らず自由走行速度で走行するとしている。 自由走行速度は道路の規格を表す指標として，階層ごと に設定する. 実際の単路部においては, 沿道出入や路上 駐車による遅れが生じるが，これらはミクロ要因による ところが大きく, 旅行時間関数に直接組み込むことが容 易でない，このため，沿道出入や路上駐車を許可する階 層の道路では，図-4のように自由走行速度を本来の值よ り低減して設定することで間接的に対応するものとする. 大型ショッピングセンターに面した幹線街路など，この ような遅れが顕著な場合については, 早河・中村15)よ゙ の既往研究を参考に，さらなる検証が必要であろう。

交差点遅れは，表-1に示寸ように，リンクとノードの 接続方法を適切に対応させるとともに, 形式に応じて異 なる遅れ関数を導入することで，図-3に描くような対向 方向・交差方向からの交通による影響を表現する. 簡略 化のため, ある平面交差点において発生する遅れは, 直 進・右左折・転回に関わらず一定とし, 進行方向別の遅 れは考慮しない. 各遅れ関数は, Highway Capacity Manu$\mathrm{al}^{16)}$ 参照するなどして, 以下の通り定義した.

\section{a) 全方向一時停止(AWSC)交差点}

無信号交差点に流入する道路の階層が同一で，優先関 係が定められない場合には, 全方向に一時停止を被る遅 れが生じる確率が同等にあると考えられる.このような 交差点を本研究では, 全方向一時停止交差点と定義し,

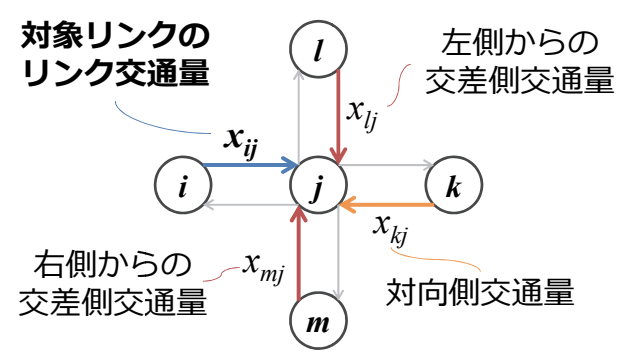

図-3 ノードに流入する複数方向リンクの接続関係

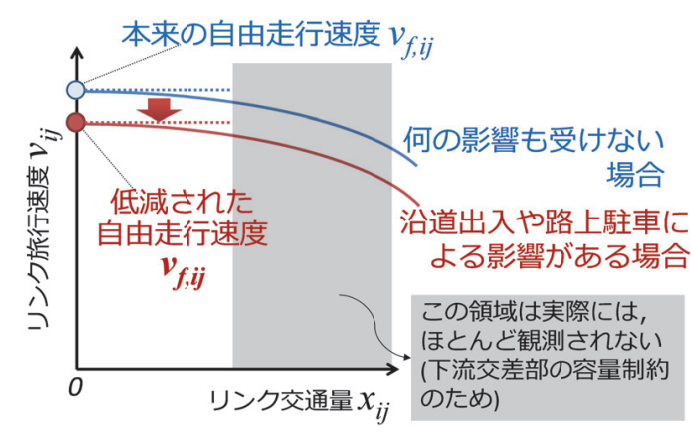

図-4 単路部走行時の交通量と旅行時間の関係 
表-1 交差形式別のリンク・ノード接続関係と妥当な階層

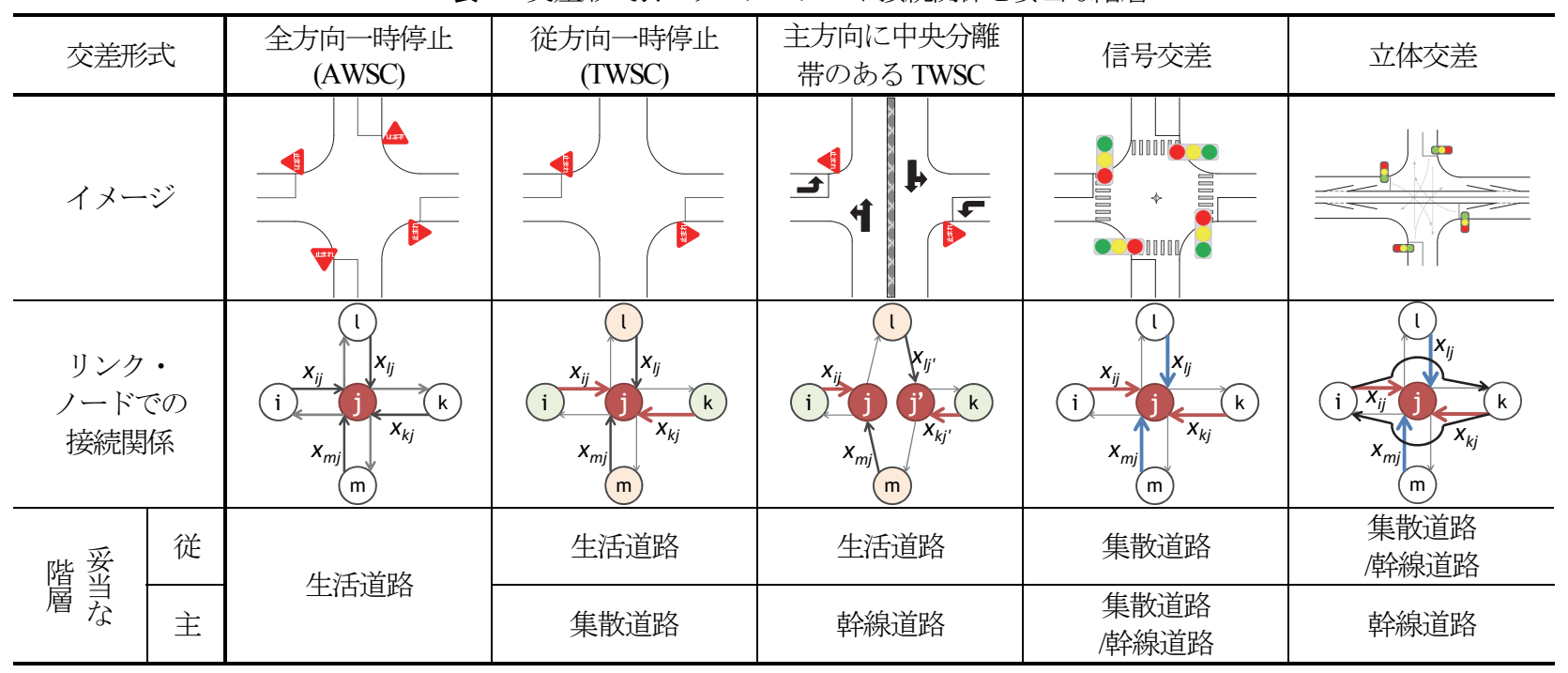

以降, AWSC (All-Way Stop-Controlled)交差点と呼ぶ.

一般的にこのような無信号交差点は，交通需要の低い 生活道路間のみに設置可能であるため, 遅れは一様に $3[\mathrm{sec}]$ をちた(式(2)).

$$
d_{A W S C, i j}=3
$$

\section{b) 従方向一時停止交差点(TWSC)交差点}

TWSC (Two-Way Stop-Controlled)交差点とは, 従方向の みに一時停止標識が設置され，従方向からの車両は，主 方向からの交通がある場合にはこれが通過するのを待っ てから流入しなければならない無信号交差点である.

本研究では, 既述の通り右左折による遅れは考慮せず, 主方向であれば遅れは発生しないものとした(式(3)). 一 方, 従方向では, 主方向の車両の到着がポアソン分布に 従うと仮定すると，ギャップ選択による遅れが式(4)の ように生じる.

$$
\begin{gathered}
d_{T W S C, \text { major }}=0 \\
d_{T W S C, \text { minor }, i j}\left(\mathbf{x}_{j}\right)
\end{gathered}
$$

$$
=\frac{3600}{c_{i j}}+900 T\left[\frac{x_{i j}}{c_{i j}}-1+\sqrt{\left(\frac{x_{i j}}{c_{i j}}-1\right)^{2}+\frac{\left(\frac{3600}{c_{i j}}\right)\left(\frac{x_{i j}}{c_{i j}}\right)}{450 T}}\right]+5
$$

$$
\begin{aligned}
& c_{i j}\left(\mathbf{x}_{j}\right)=x_{c, i j} \frac{e^{-x_{c, i j} t_{c r} / 3600}}{1-e^{-x_{c, i j} f_{j o l o w} / 3600}} \\
& x_{c, i j}=\max \left(x_{T W S C, \text { major }, l j}, x_{T W S C, \text { major }, m j}\right)
\end{aligned}
$$

ここに, $t_{c r}$ : クリティカルギャップ(6.5[sec]とする), $t_{\text {oblow }}$ : フォローアップタイム $(4.0[\mathrm{sec}]$ とする $), T:$ 遅れ計 算を行う対象時間(15[min]とする)， $c_{i j}$ : 主方向交通量か ら計算される交差点交通容量, $x_{c i j}$ : リンク $i j に$ 対する交 錯交通量である.

\section{c）主方向に中央分離帯のある一時停止交差点}

TWSC交差点の主方向に中央分離帯が設置される場合, 主方向では右折が，従方向では直進と右折が不可能とな

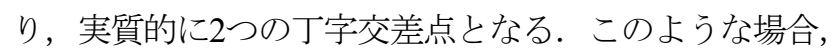
表-1のようにノードを追加してリンクを結合し直し，そ れぞれのノードをTWSC交差点とみなすことで, 主方向 (式(3)), 従方向(式(4))の遅れ計算をそれぞれ行う.

ただし，中央分離帯の設置によって，従方向では左折 流入のみとなり，特に主方向側道路が多車線の場合には， 1車線分のみギャップ選択を行えば良いことになる．本 研究では, 主方向側の車線利用率に偏りがないものとし て, 主方向側の交通量を主方向の車線数 $N_{\text {mgjor }}$ て除すこと により交錯交通量を計算し，式(4c)を式(4c')に置き換え ることで対応する.これにより, 中央分離帯を設置した 場合には, 通常のTWSC交差点に比べて, 従方向からは 左折流入のみとなるが遅れは減少する.

$$
x_{c, i j}=\frac{x_{T W S C, m a j o r, m j}}{N_{\text {major }, m j}}
$$

\section{d) 信号交差点}

信号交差点は，単独で，図-5に示すように単純二現示 制御されるとし, 右左折に伴う遅れは考慮しない. 飽和 交通流率は一車線あたり $s[\mathrm{veh} / \mathrm{h}]$ を車線数 $N_{i j}$ で乗じた值と する. ただし，損失時間Lは一定とする.

信号交差点での遅れは式(5a)で表され， degree of saturationが1を超過すると，過飽和による遅れが一定時間Tの 間加算され続ける. 式(5b), 式(5c)に示寸通り, サイクル 長と青時間は, 当該交差点への流入交通量に対して, 遅 れを最小化するように設定される．どちらもノード浘 


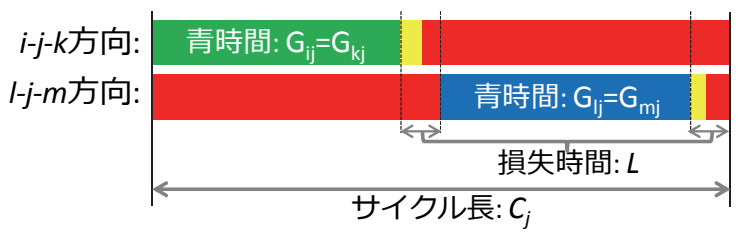

図-5 信号交差点遅れ計算時の現示設定

流入する各リンク交通量の関数であるので，非飽和・過 飽和に関わらず遅れはこれらの交通量に対する増加関数 となる. なお, 遅れ関数の急激な変曲点を避けるため, 最小最大青時間スプリットの制約は設けていない。し たがって，交差する交通量に大きく偏りがある場合，現 実的でない青時間配分が行われてしまう場合があること， 全青時間が一方向に与えられた場合にも損失時間Lだけ の遅れが発生してしまうことに注意を要する。このよう な結果となった場合には，一方通行化の検討も視野に入 れるべきであろう。

$$
d_{s i g, i j}\left(\mathbf{x}_{j}\right)=\left\{\begin{array}{l}
\frac{C_{j}}{2} \frac{\left(1-\frac{G_{i j}}{C_{j}}\right)^{2}}{\left(1-\frac{x_{i j}}{s N_{i j}}\right)} ; i f . Y_{i j}<1 \\
\frac{C_{j}}{2}\left(1-\frac{G_{i j}}{C_{j}}\right)+\frac{C_{j}\left(Y_{i j}-1\right)}{2 Y_{i j}}\left(\frac{T}{C_{j}}+2\right) ; \text { otherwise }
\end{array}\right.
$$

$$
\begin{gathered}
G_{i j}\left(\mathbf{x}_{j}\right)=\frac{\lambda_{i j}}{\lambda_{j}}\left(C_{j}-L\right) \\
C_{j}\left(\mathbf{x}_{j}\right)=\frac{1.5 L+5}{1-\lambda_{j}}
\end{gathered}
$$

ここに, $L:$ 損失時間(10 [ $\mathrm{sec}]$ とする), $s: 1$ 車線あたり 飽和交通流率(2000[veh/h] と寸る), $T$ : 過飽和遅れ加算時 間, $C_{j}$ :ノード $j$ のサイクル長(最大で200[sec]とする), $G_{i j}$ : リンク $i j の$ 青時間, $Y_{i j}=\left(x_{i j} C_{j}\right) /\left(s N_{i j} G_{i j}\right):$ degree of saturation, $\lambda_{j}=\lambda_{i j}+\lambda_{j j}:$ ノード $j$ の需要率, $\lambda_{i j}=\lambda_{k j}=\max \left\{\left(x_{i j} / s N_{i j}\right)\right.$, $\left.\left(x_{k j} / s N_{k j}\right)\right\}: i-j-k$ 方向の需要率, $\lambda_{j}=\lambda_{m j}=\max \left\{\left(x_{j} / s N_{i j}\right)\right.$, $\left.\left(x_{n j} / s N_{m j}\right)\right\}$ : 交差側方向の需要率, $x_{k j}$ : 対向側交通量, $x_{j}$, $x_{m j}$ : 交差側交通量である.ノード $i, j, k, l, m$ の関係は図-3 に示した通りである.

\section{e) 立体交差}

交通量レベルの非常に高い道路どうしが交差する場合, 直進方向を立体交差させることにより遅れを解消させ， 右左折の文信号制御を行う手段が考えられる.

このような場合には，表-1に示す通り，立体化する直 進方向 $i-j-k$ のみノード $j$ を介さずに通行可能なリンク $i k$ を張ることでノード $j$ での遅れをゼロとし，右左折につ いてはノード $j$ に信号交差点を設置することで, 式(5)か
ら信号交差点遅れを計算する.リンク $i k$ の遅れは常に

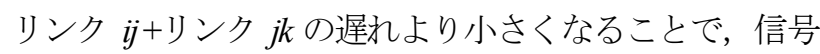
交差点ノード $j$ の直進方向規制が間接的に表現される.

\section{（2）緩和法を用いた均衡解導出方法}

前節のように複数リンクの交通量からなる旅行時間関 数を設定すると，利用者均衡配分問題はリンク間相互干 渉のある問題となる。 このような問題の解法として，本 論文では「緩和法」17を用いる。緩和法とは，一般的な 均衡配分の繰り返し計算において，本来相互干渉のある 旅行時間関数を用いるところを，相互干渉のある部分を 固定した近似的な旅行時間関数に置き換えた緩和問題を 繰り返し解く方法である.

本研究では，Frank-Wolfe 法を用いた繰り返し計算を行 い，繰り返し計算中では目的関数 $Z$ を緩和問題として式 (6)のように記述し最小化を行う. すなわち，目的関数 $Z$ の最小化プロセスにおいては, リンク旅行時間 $t_{i j}$ は対象 リンク交通量 $x_{i j}$ のみに依存するため, $x_{i j}$ について微分可 能な関数となり, 従来の手法で計算を行うことができる. この手法を用いたとき，式(6)の非積分項において対向 側・交差側交通量は固定されるが，式(5)のように，信 号交差点のサイクル長・青時間などのパラメータは, 対 象リンク交通量に応じた関数となる.

$$
Z^{n+1}=\sum_{i \in I} \sum_{j \in J} \int_{0}^{x^{n+1}} t_{i j}\left(\omega, x_{k j}{ }^{n}, x_{l j}{ }^{n}, x_{m j}{ }^{n}\right) d \omega
$$

緩和法により収束解が得られれば，これを均衡解とみ なせることが証明されている. しかし, 緩和法は解の収 束を保証するものではない点に加え，式(1) (5)のように リンク間相互干渉のある旅行時間関数を設定した場合に 均衡解が常に存在するとは保証されていない点, $\partial t_{i j} / \partial x_{i j} \geq 0$ であり $x_{i j}$ について狭義の単調増加とは限らず 解の一意性が保障されない点に留意が必要である. 以上 のような課題を残しつつも, 本研究の主眼はあくまで階 層型ネットワーク評価の枠組みの提案であることを踏ま え, 本論文では計算結果から収束状況を確認し, 解の安 定性を判断するにとどめた.

\section{（3）本手法による信号交差点遅れ計算に関する留意点}

信号交差点の遅れ計算に際しては，サイクル長や青時 間の設定に大きく依存することに配慮しなければならな い. 本研究が評価対象とするのは, 道路構造や交差形式 の決定など，信号パラメータ設定よりもさらに長期的施 策に関する事項であり，個別交差点のパラメータ最適化 までは必ずしも目的としていない，とはいえ，合理的な パラメータ設定が容易でない計画段階において，全ての 值を任意に固定することは避けるべきである.

本研究では, 前節d)で述べた通り, 信号交差点遅れに パラメータ計算を内生化した旅行時間関数を用いて，均 
衡配分を行っている. これは現実的には，全信号交差点 において，流入交通量から逐次最適パラメータを調整す る感応式制御が導入された状況と捉えられる.

これら信号パラメータの設定は，交通管理者による社 会的最適化を理想とすれば，個人便益最適化を目的とし た利用者均衡より上位の問題として設定し，二段階最適 化問題(例えばZiyou and Yifan $\left.{ }^{18) や T e k l u ~ e t a l . ~}{ }^{19}\right)$ により 計算す ることが通例である. しかし現実的に運用されている信 号制御では，利用者の行動に追従する形で感応制御を採 用する場面は少なくない.このため，本手法は実態を考 慮した道路状況を表現するに足るものと考える. 上述の 社会的最適化を実現するパラメータ設定や, 共通サイク ル長を用いた系統制御などの影響については，今後の課 題とする.

\section{5. 階層化シナリオの設定}

本章では，機能的階層型ネットワーク評価のケースス タディとして, 仮想ネットワークを定義し, 交差形式・ 自由走行速度の変更を行う複数のシナリオを設定する.

\section{（1）仮想ネットワークの道路配置}

ケーススタディの対象として，今回は，三階層の都市 内格子状ネットワークを想定する. 一つの都心をもつ都 市域を表現でき，かつ計算負荷の少ない大きさとして，

図-6に示すような，一辺0.1 [km]の格子をつなぎ合わせた $2.4[\mathrm{~km}]$ 四方のネットワークとする.このネットワーク は，立体交差や中央分離帯の設置を行わない場合には， 全625ノード，2400の有向リンクを持つことになる.

今回は生活道路をレベルI, 集散道路をレベルII, 幹線 道路をレベルIIIとした三階層に分類する.これは，トラ フィック機能とアクセス機能のトレード・オフを考慮す れば，それぞれに特化した二種類の道路と，両者を接続 する役割を持つ道路の, 少なくとも三階層が必要である と考えるためである.

各階層の配置は, 名古屋市中心部の主要幹線道路など の道路配置間隔を参考にしながら決定した。本論文は交 差形式による影響の評価に主眼を置いているため, 階層 数と道路間隔は所与とする.

3.(1)で述べた通り, 今回は容量による評価は行わない. このため, 後述するOD分布特性を考慮し, 明らかに需 要の集中するレベルIII道路についてのみ2車線, その他 は1車線とした。

\section{（2） OD交通需要の設定}

道路利用者は，起終点の両方が対象ネットワーク内に 存在する内内トリップ, 起終点のどちらかだけが存在し ネットワーク外部とのアクセス/イグレスを行う内外外

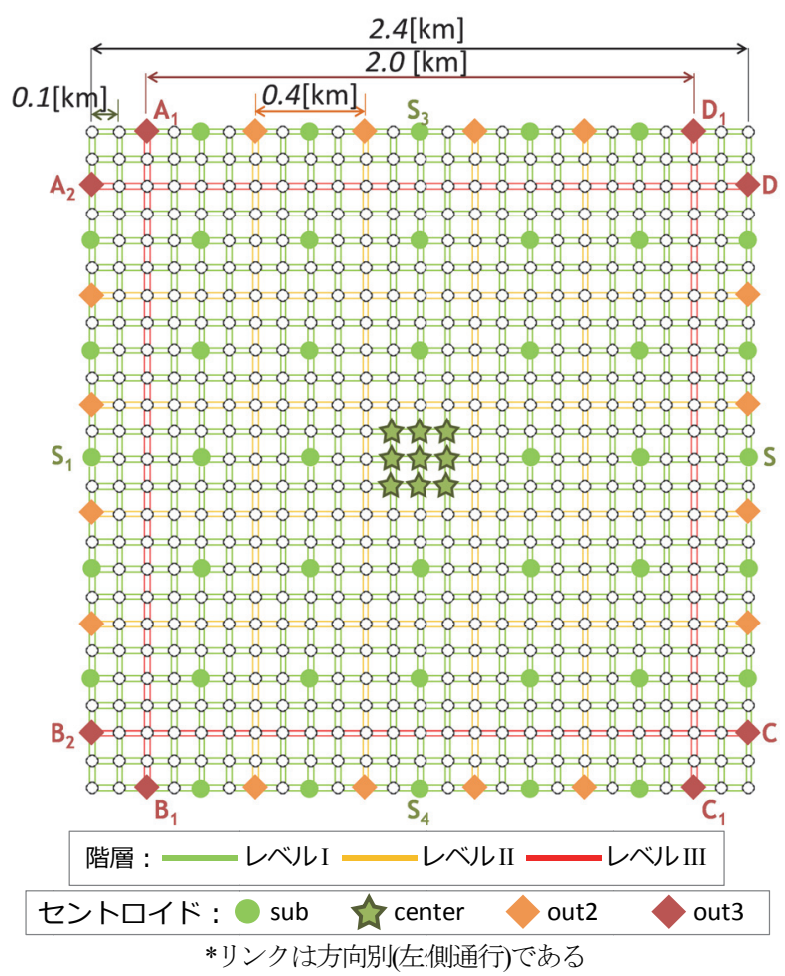

図-6 三階層ネットワークでの道路と起終点の配置

内トリップ, 起終点のどちらもネットワーク内に存在し ない通過(外外)トリップに分けられる.これらを表現す るため, sub, center, out2, out3の4種類の起終点セント ロイドを図-6の通り配置した。このうち，subとcenterは ネットワーク内に存在する起終点で，subはネットワー ク中に広がる生活区域を代表するもの, centerは都心を 代表するものである，out2およびout3はそれぞれレベルII， IIIの端末に位置し, ネットワーク外部とのやり取りを表 すものである.

これら4種類の起終点セントロイドの組み合わせごと に，表-2に示す通り交通需要老設定した。 中部地方にお ける平成17年道路交通センサス $\mathrm{OD}$ 調査による名古屋 $2 \mathrm{~km}$ 都市圈の朝ピーク時交通量を参考に, 内内トリップ, 内外外内トリップ数を概ね合わせるとともに，トリッ プ長のバランスや，都心の過度な混雑を避けることなど を考慮した。通過トリップについては，OD調査による データからは把握できないため任意に与えた。ここでは， 内外外内トリップは, ネットワーク外部にある終点も しくは起点からの距離に応じてレベルII(out2), もしくは レベルIII (out3)を経由して対象ネットワークにアクセス/ イグレスを行うと仮定している．一方，通過トリップは 長距離移動のため, 全て最上位階層であるレベル III(out3)を経由して対象ネットワークに流出入すると仮 定しており，図-6の $\mathrm{A}_{1} \Leftrightarrow \mathrm{B}_{1}, \mathrm{~A}_{2} \Leftrightarrow \mathrm{D}_{2}$ などのように直線方向 に通過するものと, $\mathrm{A}_{1} \Leftrightarrow \mathrm{C}_{1}, \mathrm{~A}_{1} \Leftrightarrow \mathrm{C}_{2}$ などのように対角方向 に通過するものの2種類を想定している. 今回設定した 交通需要の特性として, 通勤交通のような内外外内卜 
表-2 トリップ種類に対応した起終点セントロイドの組み合わせとトリップ数

\begin{tabular}{|c|c|c|c|c|}
\hline トリップ種類 & 起終点セントロイド & 需要配分条件 & 各ODペアのトリップ数[veh/pair] & 総トリップ数 $[\mathrm{veh}]$ \\
\hline \multirow{3}{*}{ 内内 } & \multirow{2}{*}{ sub-sub } & トリップ長 $>1[\mathrm{~km}]$ & 1 & \multirow{2}{*}{1656} \\
\hline & & トリップ長 $>2[\mathrm{~km}]$ & 2 & \\
\hline & sub-center/center-sub & トリップ長 $>1[\mathrm{~km}]$ & 4 & 1760 \\
\hline \multirow{4}{*}{ 内外外内 } & out2-sub/sub-out2 & - & 2 & 4224 \\
\hline & out2-center/center-out2 & - & 3 & 576 \\
\hline & out3-sub/sub-out3 & - & 12 & 12672 \\
\hline & out3-center/ center-out3 & - & 18 & 1728 \\
\hline \multirow{2}{*}{ 通過 } & \multirow{2}{*}{ out3-out3 } & 直線方向 $\left(\mathrm{A}_{1}-\mathrm{B}_{1}\right.$ など $)$ & 100 & \multirow{2}{*}{3200} \\
\hline & & 対角方向 $\left(\mathrm{A}_{1}-\mathrm{C}_{1}\right.$ など $)$ & 50 & \\
\hline \multicolumn{4}{|c|}{ 合計 } & 25816 \\
\hline
\end{tabular}

リップの占める割合が高い一方で，内内トリップは，全 体の15\%以下にとどまっていることが挙げられる.

\section{（3）階層化シナリオ}

シナリオは，まず機能的階層性の維持が困難なように 基本ケースを設定し，これに対して，機能的階層化が実 現するような対策を段階的に行うように，各階層におけ る自由走行速度と階層間交差形式を変更していく.

ただし，今回は交差形式の変更による円滑化対策およ び自由走行速度の変更による交通静穏化対策を主な評価 対象とするため，レベルIIおよび而の自由走行速度はそ れぞれ $40[\mathrm{~km} / \mathrm{h}] ， 60[\mathrm{~km} / \mathrm{h}]$ で共通とし，交差形式につい ても評価対象に対して適切かつ現実的に検討が妥当と考 えられるもの(表-3[交差形式arc])のみに限定して変更を 行った。レベルI道路じうしが交わる交差点(以降，「I-I 交差点」のように表す)については，高い交通量が期待 されず，方向別優先度は等しいため，AWSC交差点とし， 変更を行わない，また，II-II交差点およびII-III交差点に ついては，両方向から比較的高い交通量が流入すると予 測されるとともに，集散道路の役割を担うレベルIIでの 中央分離帯設置や立体交差化が必ずしも現実的ではない と考えられるため, 全て信号交差とした.

基本ケース：2.(3)で述べたように，現状のネットワー クでは階層化達成を困難にする主要な原因は信号交差点 による遅れであると考えられる，これを表現するため， このシナリオでは，レベルIIおよびレベルIIIに高密度で 信号交差点を設置する．既定であるII-II交差点，II-III交 差点のほかに，I-III交差点，I-II交差点の3分の1を信号交 差(他はTWSC交差), 最上位階層が交わるIIIIIII交差点も 信号交差とする。このとき，レベルIIまたはレベルIII上 では， $0.2[\mathrm{~km}]$ ごとに信号交差点が設置されている。こ のシナリオでは，交通静穏化対策も不十分であることを 表現するため, レベルIの自由走行速度を $30[\mathrm{~km} / \mathrm{h}]$ とし， レベルIとの差が小さくなるようにした.

基本ケースからの階層化実現のために，本論文では， 「上位階層の円滑性向上が下位階層のアクセス性向上や
表-3 検討を行った階層別交差形式

\begin{tabular}{|c|c|c|c|}
\hline 主 & I & II & III \\
\hline I & AWSC & $\begin{array}{l}\text { TWSC/信号 } \\
\text { [交差形式 c] }\end{array}$ & $\begin{array}{c}\text { TWSC / 分離帯付 TWSC } \\
\text { / 信号 } \\
\text { [交差形式a] }\end{array}$ \\
\hline II & & 信号 & 信号 \\
\hline III & & & $\begin{array}{l}\text { 信号/立体 } \\
\text { [交差形式b] }\end{array}$ \\
\hline
\end{tabular}

通過交通排除を図る上でも重要である」との仮説をおく この仮説の下，まず最上位であるレベルIII円滑化を目標 として，レベルIII信号減少ケースでI-III交差点の信号を 全てTWSCに変更，中央分離帯ケースでこれらTWSC交 差点に中央分離帯を設置，さらに立体交差化ケースで III-III交差点の立体交差化を行う。これらにより，レベル III道路では信号交差点による遅れが著しく減少すると期 待される．続いて，レベルII円滑化を目的として，レ心゙ ルII信号減少ケースでI-II交差点の信号をTWSCに変更す る．このような円滑化対策を全て行った後に，交通静穏 化対策として，交通静穏化ケースでレベルIの自由走行 速度を $30[\mathrm{~km} / \mathrm{h}]$ から $20[\mathrm{~km} / \mathrm{h}]$ に低減する。

交通静穏化ケースは，階層化実現のために必要と考え られる対策を全て導入したシナリオであるが，これに対 して配分計算を行ったところ, cityセントロイド周辺に おいて，レベルПの交通量増加により，レベルと交差す るTWSC交差点において著しい過飽和遅れが発生してし まい，階層化の効果を評価するのに適切でないことが分 かった(3.(1)). このような, 主方向従方向どちらの需要 も高い道路の交差点では，信号を設置することはやむを 得ないと考え，cityセントロイドを囲むレベルIIの四方向 1か所ずつを信号交差点とし，過飽和を解消した。この シナリオを，階層化実現のための対策が全て行われたも のとして階層ケースと呼び，次章ではこれを用いて機能 的階層性の効果を検証する.

また，上記の「円滑化対策を行ってから交通静穏化対 策を行う」という仮説に相反するシナリオとして，基本 
表-4 各シナリオにおける自由走行速度と交差形式の変化

\begin{tabular}{|c|c|c|c|c|c|}
\hline 目的 & シナリオ & $\begin{array}{l}\text { I-III交差点 } \\
\text { [交差形式 a] }\end{array}$ & $\begin{array}{c}\text { III-III 交差点 } \\
\text { [交差形式 b] }\end{array}$ & $\begin{array}{l}\text { I-II 交差点 } \\
\text { [交差形式 c] } \\
\end{array}$ & $\begin{array}{c}\text { レベル I道路の } \\
\text { 自由走行速度 }[\mathrm{km} / \mathrm{h}]\end{array}$ \\
\hline- & 基本 & 信号または TWSC & 信号 & 信号または TWSC & 30 \\
\hline \multirow{3}{*}{ レベル III 円滑化 } & レベル III 信号減少 & 全て TWSC & 信号 & 信号または TWSC & 30 \\
\hline & 中央分離帯 & 全て分離帯付 TWSC & 信号 & 信号または TWSC & 30 \\
\hline & 立体交差化 & 全て分離帯付 TWSC & 立体交差 & 信号または TWSC & 30 \\
\hline +レベル II 円滑化 & レベル II 信号減少 & 全て分離帯付 TWSC & 立体交差 & 全て TWSC & 30 \\
\hline \multirow[b]{2}{*}{ +レベル I静穏化 } & 交通静穏化 & 全て分離帯付 TWSC & 立体交差 & 全て TWSC & 20 \\
\hline & 階層 & 全て分離帯付 TWSC & 立体交差 & $\begin{array}{c}\text { TWSC } \\
\text { (都心に4 ヶ所, 信号設置) }\end{array}$ & 20 \\
\hline レベル I静穏化 & 交通静穏化のみ & 信号または TWSC & 信号 & 信号または TWSC & 20 \\
\hline
\end{tabular}

ケースから円滑化対策を全く行わずに，レベルIの自由 走行速度を低減する交通静穏化のみケースを設定した。

今回設定したシナリオの，基本ケースからの段階的な 変更は表-4のようにまとめられる.

\section{（4）均衡配分計算の収束状況}

前節でこれらの全てのシナリオに対して，4.の手法に より交通量配分を行った. 4.(2)で述べた通り，本研究で 用いる緩和法による配分は，常に収束が保障されるもの ではないため，本節では，全シナリオの収束状況につい て，BPR 関数を用いた一般的な配分手法と比較し，解 の妥当性を確認する.

比較対象として，格子の全てが結合している基本ケー スを用い，旅行時間関数をノードjの交差形式に依らず 式(7)のBPR関数で定義した配分計算を行った. これを基 本(BPR関数)ケースと記載する.

$$
t_{i j}\left(x_{i j}\right)=\frac{l_{i j}}{v_{f, i j}}\left\{1+\alpha\left(\frac{x_{i j}}{C A P_{i j} N_{i j}}\right)^{\beta}\right\}
$$

ここに，パラメータ $(\alpha, \beta)$ には修正BPR関数の值 $(2.62$, 5.00)を用い，CAP $P_{i j}$ にいては，一般的な信号交差点で の容量を想定し, サイクル長 $100[\mathrm{sec}]$ で青時間スプリッ ト $=0.5$ の場合の 1 車線あたりの交通容量と等しい $900[\mathrm{veh} / \mathrm{h}]$ を便宜的に設定した.

今回のケーススタディでは, 繰り返し計算の収束条 件は, 目的関数の変動值 $\left(d Z^{n+1}=\left|Z^{n+1}-Z^{n}\right| ; n\right.$ は繰り返し回 数 $) \leq 1.0$ [veh*sec], 最大 500 回打ち切りとした. 前者は, 今回対象とするネットワーク規模と交通需要の下では, 目的関数の変化率 $\left(=d Z^{n+1} / Z^{n}\right)$ が $1.6 \times 10^{-6}$ 程度となるまで 計算を続けることを意味している.

計算の結果，中央分離帯ケース，交通静穏化ケースお よび階層ケースでは，目的関数の収束条件が達成されず， 500回で計算打ち切りとなった。ただし，これは基本 (BPR関数)ケースにおいても同様であったことから，全 シナリオについて，計算終了時の目的関数の変化率に加 え，これと同様に収束判定指標として用いられることが
表-5 各シナリオの収束状況

\begin{tabular}{|c|c|c|c|c|}
\hline シナリオ & $\begin{array}{l}\text { 計 } \\
\text { 算 } \\
\text { 回 } \\
\text { 数 }\end{array}$ & $\begin{array}{c}\text { 目的関数 } \\
\text { 変化率 }\end{array}$ & $\begin{array}{c}\text { リンク } \\
\text { 交通量 } \\
\text { 変動 } \\
\text { [veh] }\end{array}$ & $\begin{array}{l}\text { リンク } \\
\text { 交通量 } \\
\text { 変化率 }\end{array}$ \\
\hline 基本 & 432 & $1.4 \times 10^{-7}$ & 3.0 & 0.0016 \\
\hline レベル III 信号減少 & 309 & $5.3 \times 10^{-9}$ & 3.9 & 0.012 \\
\hline 中央分離帯 & 500 & $7.7 \times 10^{4}$ & 6.0 & 0.0054 \\
\hline 立体交差化 & 280 & $9.0 \times 10^{-8}$ & 3.1 & 0.019 \\
\hline レベル II 信号減少 & 365 & $1.3 \times 10^{-7}$ & 1.9 & 0.0084 \\
\hline 交通静穏化 & 500 & $2.9 \times 10^{4}$ & 2.6 & 0.0076 \\
\hline 階層 & 500 & $1.8 \times 10^{6}$ & 1.3 & 0.0040 \\
\hline 交通静穏化のみ & 263 & $1.5 \times 10^{-8}$ & 2.2 & 0.0016 \\
\hline 基本(BPR 関数) & 500 & $2.7 \times 10^{6}$ & 4.7 & 0.0019 \\
\hline
\end{tabular}

斜字は最大 500 回で打ち切りとなったシナリオ

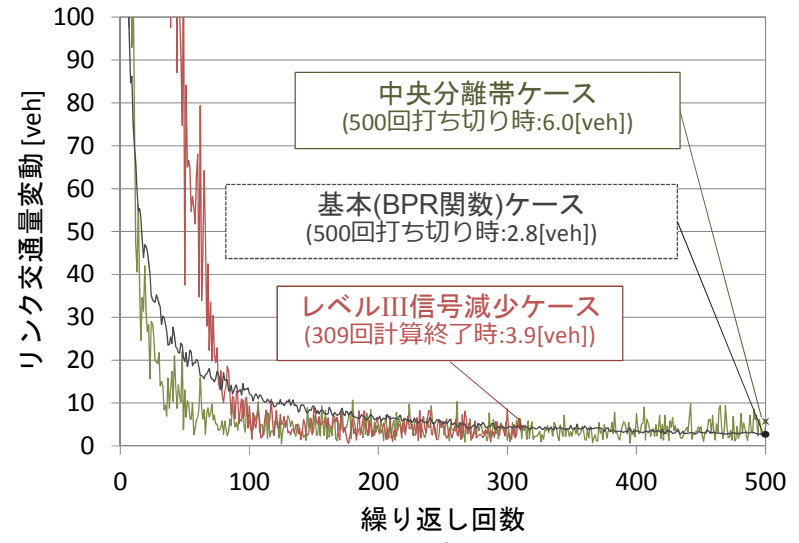

図-7 リンク交通量変動の収束状況

一般的な, リンク交通量変動 $\left(d x_{r s}{ }^{n+1}=\left|x_{r s}{ }^{n+1}-x_{r s}{ }^{n}\right|\right.$, ただし $\left|x_{r s}{ }^{n+1}-x_{r s}{ }^{n}\right|=\max _{(i, j)}\left(\left|x_{i j}{ }^{n+1}-x_{i j}{ }^{n}\right|\right)$ およびリンク交通量変化率 $\left(=d x_{r s}{ }^{n+1} / x_{r s}{ }^{n}\right)$ を確認した。 その結果を表-5に示す.

表-5をみると, 目的関数の収束条件が達成されなかつ た中でも中央分離帯ケースおよび交通静穏化ケースでは 目的関数変化率が比較的高い值となっているが， $0.01 \%$ 未満にとどまっている.リンク交通量変動は最大で 6.0 [veh](中央分離帯ケース), この変化率も最大で約 $2 \%$ 以下(レベルIII信号減少ケース)であり，解は安定してい るといえよう。ささらに，目的関数変化率およびリンク交 
通量変動が最大であった中央分離帯ケース，リンク交通 量変化率が最大であったレベルIII信号減少ケースについ て，計算開始から収束判定までのリンク交通量変動を確 認したところ，図-7のようであつた。基本(BPR関数)厅 一ス場合と比べ，あるとき急激にリンク交通量変動が小 さくなる点, 変動量の振れ幅がやや大きい点に差異があ り，これらは内生化された信号パラメータ計算に伴う急 激な遅れの変化によるものと考えられる.このような差 異があるものの, 解が徐々に安定する様子は確認できた ことから，収束判定は妥当であると判断した。

\section{6. 交差形式の変更による階層化効果の検証}

本節では，前章で設定した各シナリオについて，3.(1) の観点から，(1)意図した機能的階層化が実現されてい るか，(2)利用者に提供されるサービス水準はどのよう な影響を受けるか，の二点を評価する.

\section{（1）機能的階層化の実現に関する評価}

本節では，5.(3)で設定した各シナリオが意図する，a) レベルIII円滑化対策，b)レベルII円滑化対策，c)レベルI 交通静稻化対策の目的ごとに，機能的階層化が実現した かどうかを検証する。評価指標として，3. (2)で定義し た階層別平均旅行速度を図-8に，通過トリップの各階層 使用割合を表-6に示す.

ここで，表-6の各階層使用割合は，トリップ長の異な る直線方向・対角方向別に求めている. 対象市ットワー クの通過トリップは，レベルIII端末にある out3(図-6)か ら流入・流出するため, 基本的に階層使用割合はレベル IIIが100\%となるはずである.しかし，レベルIIIの円滑性 が担保されない場合に，通過トリップが下位階層を使用 する可能性があり，これを本指標で確認する.

\section{a) レベル III 円滑化対策による影響}

図-8をみると，レベルIII平均旅行速度は，レベルIII信 号減少ケース，立体交差化ケースにおいて大きく上昇し， 下位階層との差別化が進んでいる，この理由は，レベル III信号減少ケースについては，信号交差点のTWSC化で
遅れの発生しないリンクが増加することにある. 中央分 離帯ケースで速度上昇がほとんどみられないのは，信号 交差点の数が変化していないことに加え, 分離帯による 迂回トリップがレベルIIIの交通量を増大させ， IIIIIII信号 交差点での遅れが著しくなったことによる.このような 上位階層が交わる箇所はキ一交差点と呼ばれ，現実にも キ一交差点での遅れが幹線道路の旅行速度を著しく低下 させている場合が多い，立体交差化ケースは，キ一交差 点の立体交差化が，レベルIII平均旅行速度を上昇させる のに極めて有効なことを証明几ているといえる.

一方で，表一の通過トリップの各階層使用割合みると， レベルIII信号減少ケースでは，(a) 直線方向・(b) 対角方 向どちらにおいても，レベルIやレベルIIの使用割合が増 加してしまっており, 通過トリップが下位階層に進入し てしまうことを意味している，これは，基本ケースでは I-III信号交差点から流入していた交通が，交差形式の変 更によってII-III信号交差点に集中し，この周辺のリンク 旅行速度が局所的に著しく低下してしまうことによる. 平均旅行速度(図-8)のみからは, 階層間の差別化が進ん だとみられたレベルIII信号減少ケースであったが，実際 には機能的階層性は保持されていないといえる. 中央分 離帯ケースでは，レベルI・II匹も使用割合がかなり抑え られており, 通過トリップの経路に制約をかけたり，I-

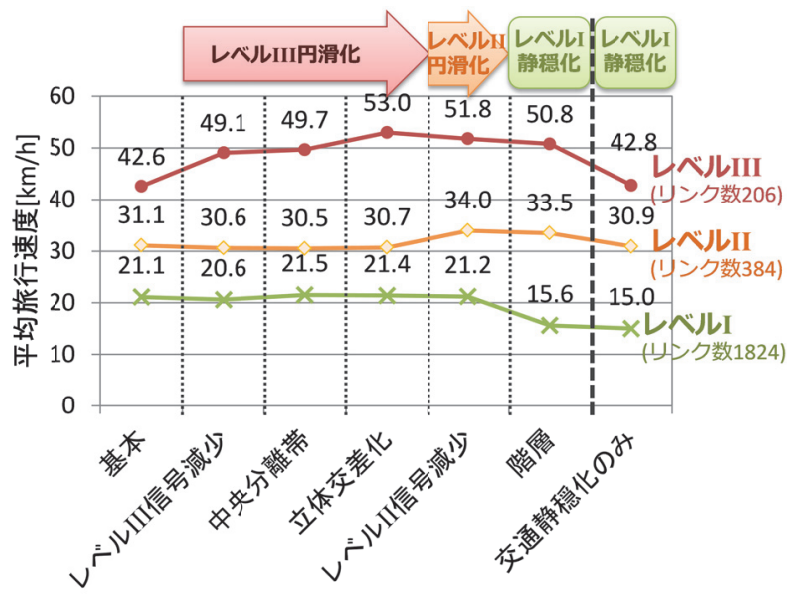

図-8 各シナリオでの階層別平均旅行速度

表-6 通過トリップの各階層使用割合

\begin{tabular}{|c|c|c|c|c|c|c|}
\hline \multirow[t]{2}{*}{ シナリオ } & \multicolumn{3}{|c|}{$\begin{array}{c}\text { (a) 直線方向通過トリップ } \\
\text { 階層使用割合[\%] } \\
\end{array}$} & \multicolumn{3}{|c|}{$\begin{array}{c}\text { (b) 対角方向通過トリップ } \\
\text { 階層使用割合[\%] }\end{array}$} \\
\hline & レベル I & レベル II & レベル III & レベル I & レベル II & レベル III \\
\hline 基本 & 0 & 0 & 100 & 3.4 & 0 & 96.6 \\
\hline レベル III 信号減少 & 10.7 & 7.1 & 82.1 & 4.5 & 38.6 & 56.8 \\
\hline 中央分離帯 & 0 & 0 & 100 & 2.3 & 0 & 97.7 \\
\hline 立体交差化 & 0 & 0 & 100 & 0 & 0 & 100 \\
\hline レベル II 信号減少 & 0 & 0 & 100 & 1.1 & 0 & 98.9 \\
\hline $\begin{array}{c}\text { 階層 } \\
\end{array}$ & 0 & 0 & 100 & 1.1 & 0 & 98.9 \\
\hline 交通静穏化のみ & 4.0 & 7.4 & 88.6 & 0 & 43.2 & 56.8 \\
\hline
\end{tabular}


III交差点での左折流入をしやすくしたりすることが，有 効に作用していることがわかる.

以上より，基本ケースに対してレベルIII信号減少，中 央分離帯，立体交差化といった対策を組み合わせること で，レベルIII円滑化が実現し，他階層との差別化が行わ れただけでなく, 通過トリップの下位階層進入抑制が達 成されたといえる.

\section{b) レベル II 円滑化対策による影響}

レベルII信号減少ケースでは，対策によりレベルIのの 旅行速度が向上し, レベルとの差別化が進んだ半面, レベルIIIの旅行速度がやや低下した(図-8)。これは，レ ベルIIの交通量増大により, II-III信号交差点の遅れが増 大するためである.

階層別使用割合は表-6の通り，通過トリップのほぼ 100\%がレベルIIIを使用することを示している.

\section{C) レベルI交通静穏化対策による影響}

階層ケースは，レベルの自由走行速度が低減される ので, 図-8の通り, レベルIの平均旅行速度が抑えられ, 階層間の差がより明確になる. 表-6より, 通過トリップ の下位階層進入もほとんど抑えられており，階層ごとの 差別化が徹底したといえよう。

一方，階層ケースに相反するシナリオとして設定した 交通静穏化のみケースでは，図-8の通り，上位階層の旅 行速度は上げられないまま, レベルの旅行速度が下げ られる．このとき，表-6では，(a) 直進方向で通過トリ ップのレベルI使用割合が約4.0\%，レベルIが約7.4\%,

(b) 対角方向でレベルII使用割合が約 $43.2 \%$ であり, 対策 の目的とは裏腹に通過トリップが下位階層へ進入してし まっていることがわかる。これは，レベル旅行速度 低下が上位階層への交通集中を招き，しかし一方で上位 階層の遅れ対策は不十分なため交通を別ききれず，通過 交通の迂回を引き起こしてしまったことを意味する.

階層ケースと交通静穏化のみケースの比較から, 交通 静穏化対策を行う際に，上位階層の円滑性を確保してお くことの重要性が示される結果となった。このことは, 機能的階層化の実現にとって，「上位階層の円滑性向上 が下位階層のアクセス性向上や通過交通排除を図る上で も重要である」という，5.(3)で立てた仮説の妥当性を証 明しているに他ならない。

\section{d) 階層化前後の旅行速度分布の比較}

a) c)より, 全ての対策を導入した階層ケースでは, 機能的階層化が実現していると考えられる. そこで，基 本ケースと階層ケースについて, リンク旅行速度分布を 図-9で比較し，より詳細な特性を把握する.

(a) 基本ケースでは，レベルIIIであっても，50\%が旅行 速度40[km/ ] を下回っており，レベルIIとの区別がほと んどない.これらはどちらの道路にも同数の信号交差点 が設置されているためで，信号交差点の設置されたリン

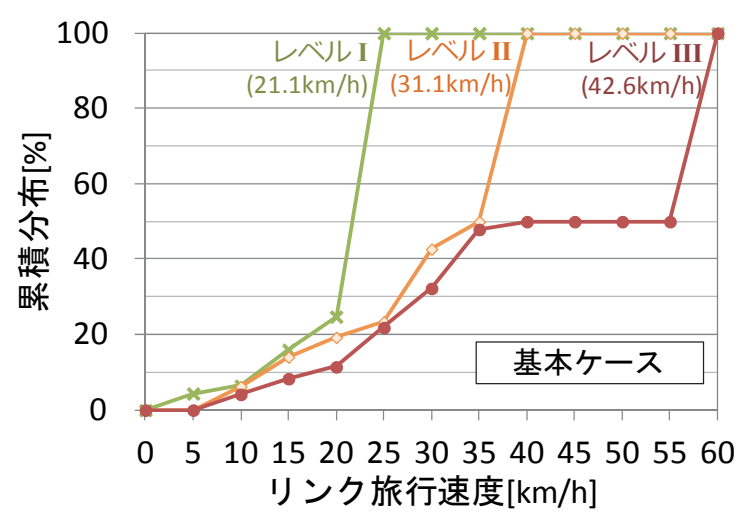

(a) 基本ケース

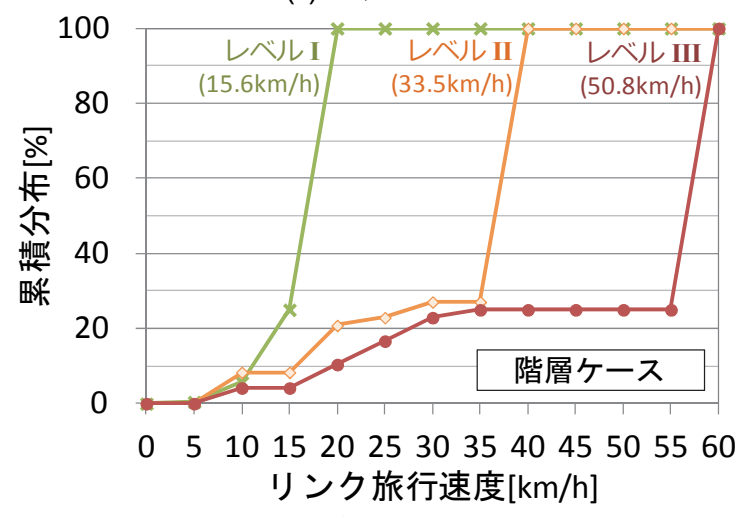

(b) 階層ケース

図-9 リンク旅行速度分布*( )内の值は平均旅行速度を表す

クでは，その遅れの影響が甚大であり，自由走行速度の 差は旅行速度にほとんど関与しないことを示唆している。 対する(b) 階層ケースでは，このような信号交差点遅 れを解消することによって，レベルIIIのうち約75\%のリ ンクで旅行速度が自由走行速度である $60[\mathrm{~km} / \mathrm{h}]$ に上昇し， 依然として遅れの影響を被るリンクが存在するものの， レベルIとの差別化が明確である.

\section{（2）利用者に対するサービス水準に関する評価}

本節では, 各シナリオのもと, 利用者に対して提供さ れるサービス水準にはどのような変化があったのかを,

3.(2)c)で定義したトリップ長別旅行時間およびその短縮 率を用いて評価する.

図-10(a)に各シナリオでのトリップ別旅行時間を，(b) に基本ケースからの旅行時間短縮率を示寸. ただしここ では, 起終点が対象ネットワーク外部にあるトリップの トリップ長の違いを間接的に表現するため, 内内・内外 外内・通過に分け，それぞれの特徵を表現可能なよう に，以下のように代表值を定義し用いている. 内内トリ ップは，トリップ長 $1[\mathrm{~km}]$ 以上となる任意のsub-sub間お よびsub-city間(図-6，表-2)に配分されているが，旅行時 間の評価は，図-6における $\mathrm{S}_{1} \Leftrightarrow \mathrm{S}_{2}, \mathrm{~S}_{3} \Leftrightarrow \mathrm{S}_{4}$ の $4 つ の$ sub-sub間 トリップの平均旅行時間を代表值として行う。なぜなら， これらが最短距離で移動しようとすると, 交通の集中す 


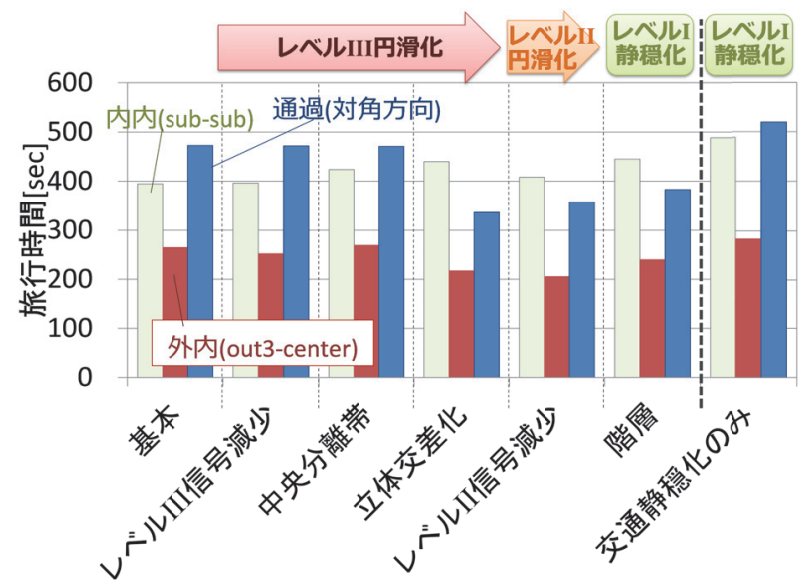

(a)旅行時間代表值

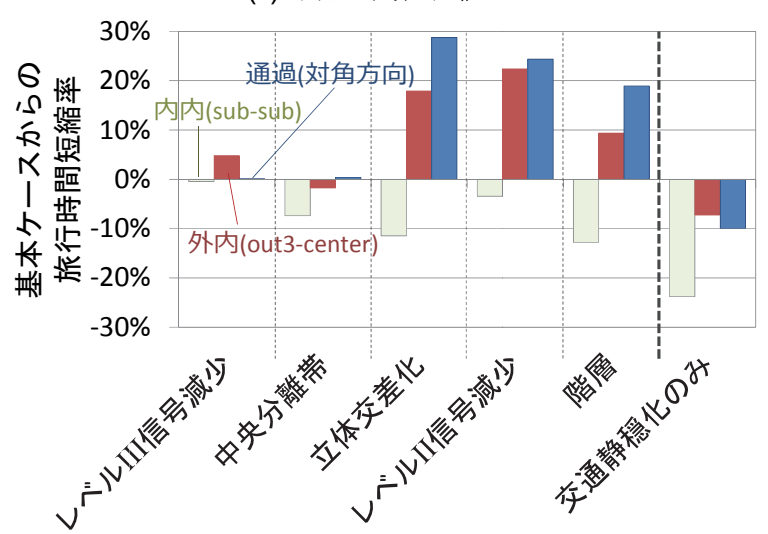

(b) 基本ケースからの旅行時間代表值の短縮率

図-10 各シナリオでの旅行時間代表值の比較

る都心を通過し，かつレベルIIIを二度横断する必要があ り，交差形式変更による従方向遅れの増大や迂回の影響 を最も受けやすいと考えられるためである.内外外内 トリップについては，都心アクセス寸なわちout3からネ ットワークに流入し， cityの中心に終着する外内トリッ プ(out3-center)の平均旅行時間を代表值とする. さらに, 通過トリップ(out3-out3)については，トリップ長の長い 対角方向について，平均旅行時間を代表値と寸る.

\section{a) レベル III 円滑化対策}

レベルIII信号減少ケースや中央分離帯ケースは，どの トリップに対しても旅行時間短縮の効果が小さいことが 分かる. 特に，これらのシナリオが期待していた通過卜 リップ旅行時間の短縮がほとんどみられない。これは， (1)で述べたように，両シナリオではレベルIII旅行速度が 平均的には上昇しているものの, 局所的な遅れが増大し ているためである。これらに対し立体交差化ケースでは, 通過トリップ旅行時間が劇的に短縮している。この結果 は，長距離トリップ利用者の円滑性を向上させるために は，信号交差点を減少させたり，中央分離帯設置を行う ことと併せてキ一交差点対策を行うことの重要性を改め て認識させるものである.

一方で，中央分離帯ケースや立体交差化ケースは，内

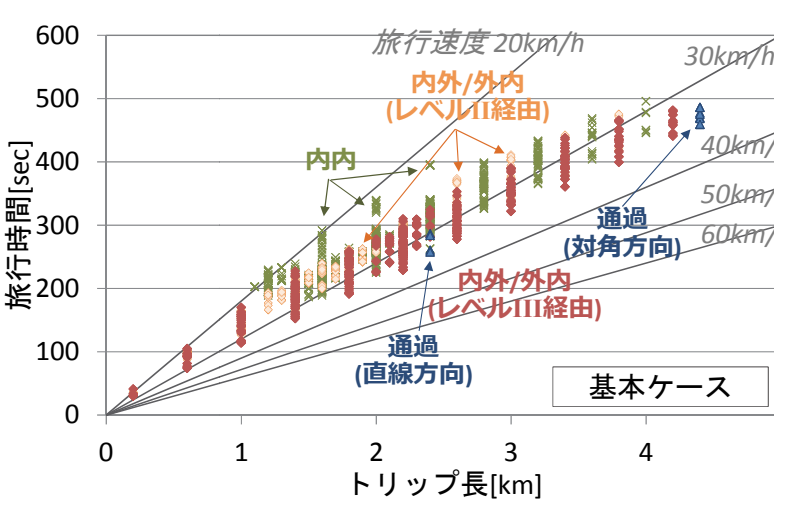

(a) 基本分一ス

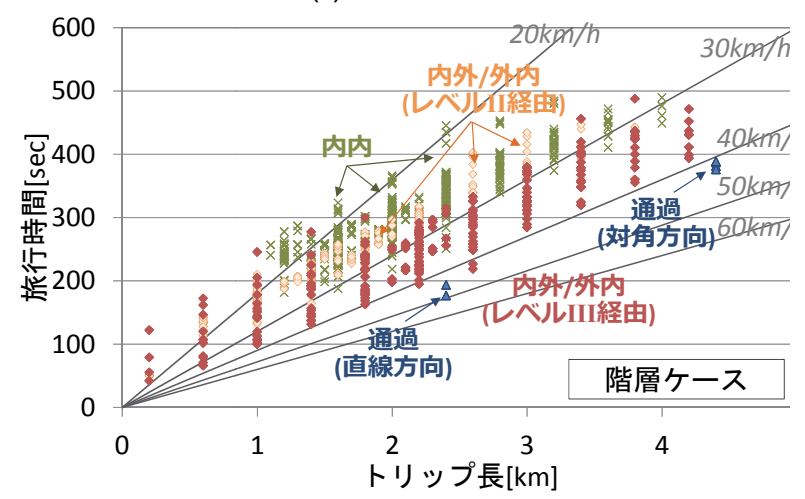

(b) 階層分ース

図-11 トリップ長別旅行時間

内トリップに迂回を強い，旅行時間を増大させてしまう という特徵もあるが，立体交差化ケースと基本ケースの 差は30[sec]程度にとどまり，生活交通である内内トリッ プにとっては許容範囲内と考えられる.

\section{b) レベル II 円滑化対策}

レベルII信号減少ケースでは，立体交差化ケースに比 ベて，内内・外内トリップに対する効果がある一方，通 過トリップには逆効果である.

\section{c) レベル I交通静穏化対策}

階層ケースでは，どのトリップについても，直前のレ ベルII信号減少ケースより旅行時間が増大し，短縮率は 減少している。しかしそもそも交通静穏化対策とは，レ ベルIのような下位階層に存在する歩行者・自転車の安 全性や快適性のための施策であり，旅行時間短縮は目的 としていない，このことを考慮すると，このシナリオは， このような対策を施しながらも，外内・通過卜リップの 旅行時間は基本ケースと比較した場合，依然として短縮 されていることから，各階層が利用者にメリハリのある サービスを提供しているといえる.

これに対して, 意図した交通静穏化が実現されないこ とが(1)で示された，交通静穏化のみケースでは，内内 トリップのみならず全てのトリップの旅行時間が増大し てしまっており, 円滑性の低下までも同時に引き起こし ていることがわかる. 


\section{d）階層化前後のトリップ別旅行時間の比較}

階層化が利用者に与える影響をより詳細に調べるため, 図-11に全トリップのトリップ長-旅行時間の関係を示寸 ここで，横軸は格子が全て結合していた場合のOD間最 短距離をトリップ長として用いている。

(a) 基本ケースではトリップ種類に関わらずトリップ 長と旅行時間の関係はほぼ一定で, 旅行速度 $30[\mathrm{~km} / \mathrm{h}]$ 前 後になっているのに対して，(b)階層ケースは，内内卜 リップ<内外外内トリップ $($ レベルI経由 $)<$ 内外/外内卜 リップ(レベルIII経由) <通過トリップの順に旅行速度が 高くなる．これは，階層別平均速度の差別化が，ネット ワーク全体として利用者に提供されるサービス水準に反 映されていることを意味する，一方，図-11(b)では，特 に内内トリップや内外/外内トリップの旅行速度の幅が 広がっていることから，階層化が，これらのトリップの 起終点位置による旅行時間のばらつきを増大させること がわかる.

以上のような，階層型ネットワークで実現されるサー ビス水準の評価を行う上で重要な特徵を, 本研究は適切 に表現可能にしたといえる.

\section{7. おわりに}

本論文では，機能的階層化の実現という観点に着目し たネットワーク評価の枠組みを提案し，仮想の三階層都 市内ネットワークを対象に，交差形式や自由走行速度を 変更した場合のケーススタディを行った。この結果，円 滑性向上のためにはキー交差点対策が久かせないことや, 円滑化対策と併せて交通静穏化対策を行う必要があるこ となど，機能的階層化を実現するためのポイントが確認 できた．また，階層型ネットワークでは，階層間の差別 化に応じて，利用者に対してもメリハリのあるサービス が提供されることが示唆された.

本研究が用いた交差点遅れを考慮した利用者均衡配分 手法は，解の存在性・一意性が保障されないという課題 の残るものである．また，信号交差点を全て独立したも のとして扱い，信号パラメータを交通量に応じて最適化 しているための課題もある. 今後, これらの妥当性につ いて精査を進めなければならない.

その上で，今後は階層数，道路間隔による影響につい て評価を行うほか，OD需要特性と階層化の効果の関係 についても, 研究を進めていきたい.

\section{参考文献}

1) 中村英樹, 大口敬, 森田綽之, 桑原雅夫, 尾崎晴 男: 機能に対応した道路幾何構造設計のための道路 階層区分の試案, 土木計画学研究・講演集, Vol. 31, CD-ROM， 2005.
2) 高橋健一，松本幹一，山川英一，阿部義典：性能照 査型道路設計における交差・出入制限と階層区分道 路の実現に向けた課題, 土木計画学研究・講演集,

Vol. 43, CD-ROM, 2011.

3) 下川澄雄, 内海泰輔, 中村英樹, 大口敬 : 道路の階 層区分を考慮した交通性能照査手法の提案，土木計 画学研究・講演集, Vol. 43, CD-ROM， 2011.

4) (社) 日本道路協会 : 道路構造令の解説と運用, 2004 .

5) 中村英樹：高級な道路の供給から合理的な機能の提 供へ，交通工学，Vol. 38 増刊号，pp. 5-13， 2003.

6) Forschungsgesellschaft für Straßen -und Verkehrswesen (FGSV) : Richtlinien für integrierte Netzgestaltung RIN, 2008.

7) Forschungsgesellschaft für Straßen -und Verkehrswesen (FGSV) : Richtlinien für die Anlage von Stadtstraßen RASt 06, 2006.

8) Friedrich, B., Friedrich, M., Priemer, C. : Impacts of the Service Quality of Single Road Facilities on the Service Quality in Networks, TRB 5th International Symposium on Highway Capacity and Quality of Service, pp. 381-390, 2006.

9) AASHTO : A Policy on Geometric Design of Highways and Streets, pp. 1-7, CD-ROM, 2004

10) Transportation Research Board : Access Management Manual, Transportation Research Board, pp. 20, 2003.

11) 桑原雅夫, 若公雅敏, 王鋭：街路の階層的配置によ るネットワーク設計に関する一考察，土木学会論文 集D3 (土木計画学), Vol. 67, No. 3, pp. 230-243, 2011.

12) 大口敬, 中村英樹, 森田綽之, 桑原雅夫，尾崎晴 男: ボトルネックベースで考える道路ネットワーク 計画設計試論, 土木計画学研究・講演集, Vol. 31, CD-ROM, 2005.

13) Miyagawa, M.: Optimal Hierarchical System of a Grid Road Network, Annals of Operation Research, Vol. 172, pp. 349-361, 2009.

14) Zhang, H. and Li, Z.: Weighted Ego Network for Forming Hierarchical Structure of Road Networks, International Journal of Geographical Information Science, Vol.25, No. 2, pp. 255-272, 2011.

15) 早河辰郎, 中村英樹 : 幹線街路における沿道アクセ ス機能に応じた旅行速度性能曲線の定式化，土木計 画学研究・講演集, Vol. 39, CD-ROM, 2009.

16) Transportation Research Board : Highway Capacity Manual 2010, 2010

17) (社)土木学会 : 交通ネットワークの均衡分析一最新の 理論と解法一, 丸善, pp. 154-158, 1998.

18) Ziyou, G. and Yifan, S.: A Reserve Capacity Model of Optimal Signal Control with User-equilibrium Route Choice, Transportation Research Part B, Vol. 36, pp. 313323, 2002.

19) Teklu, F., Sumalee, A. and Watling, D. : A Genetic Algorithm Approach for Optimizing Traffic Control Signals Considering Routing, Computer-Aided Civil and Infrastructure Engineering, Vol. 22, pp. 31-43, 2007.

(2012. 2. 25 受付) 


\section{EVALUATION OF THE FUNCTIONALLY HIERARCHICAL ROAD NETWORK CONSIDERING JUNCTION TYPES}

\section{Azusa GOTO, Hideki NAKAMURA and Miho ASANO}

A concept of the functionally hierarchical road network has been recognized with the purpose to provide the required service for road of each class. Especially in Japan, practical use of this concept has been intensively discussed from the viewpoint of both mobility improvement of arterial roads and traffic calming in local streets. However, the impact of junctions, which is regarded as a key issue of the hierarchical road network, has not been quantitatively evaluated with the performance of individual roads and further the entire network at planning stage. Therefore, in this paper, a methodology to evaluate the impacts of junction types on the performance of the network is developed by considering junction delay into user equilibrium assignment. By applying it, case studies with hypothetical grid network showed that reduction in junction delays at arterial roads is significant to realize hierarchical road network; and if it is achieved, traffic calming in local roads can also effectively work. 